\title{
SIG BERBASIS GOOGLE MAPS API TERINTEGRASI SMS GATEWAY UNTUK MEMANTAU KEGIATAN KKN
}

\author{
I Putu Suhada Agung, Sapto Hudoyo \\ Fakultas Seni Rupa dan Desain, ISI Surakarta \\ email: ipsa@isi-ska.ac.id \\ Fakultas Seni Rupa dan Desain, ISI Surakarta \\ email: sapto@isi-ska.ac.id
}

\begin{abstract}
This research is motivated by the difficulties in monitoring the implementation of Lecture of Real Work Lecture/Kuliah Kerja Nyata (KKN). Google Maps digital map application owned by Google is integrated with SMS input data from each KKN service post with various information. This system design method is to conduct initial study problems in the field, observation and literature study as well as interviews about system requirements made. Interviews were conducted to those related to KKN activities, including Coordinator and field supervisor/Dosen Pembimbing Lapangan(DPL) KKN. Research data is used to get the system needs made related to SMS input data, SMS data format, and display, as well as technical data in the field, including signal coverage and cell phone signal strength. From the data collected, it is analyzed to apply Geographic Information System (GIS) based on SMS Gateway to monitor KKN activities in real time. The use of SMS is chosen with consideration of the presence of stronger $2 G$ (phone and SMS) signals than $3 G$ and $4 G$ signals (Internet data signals) in remote locations. The SMS format used is: KKN \# LOCATION \# INFORMATION. GIS is displayed in the form of markers and windows information on the Google Maps map containing information that may change according to the content of the SMS sent from each KKN post. Furthermore the system is tested to determine the response to data sent via SMS.
\end{abstract}

Keywords: KKN, GIS, SMS.

\section{PENDAHULUAN}

\section{Latar belakang}

Kuliah Kerja Nyata (KKN) merupakan kegiatan pengabdian kepada masyarakat yang dilakukan oleh mahasiswa melalui pendekatan lintas ilmu di daerah yang sudah ditentukan melalui survei sebelum kegiatan. Pelaksanaan kegiatan KKN ISI Surakarta melibatkan Fakultas Seni Pertunjukan (FSP) dan Fakultas Seni Rupa dan Desain (FSRD) secara rutin di akhir semester genap. Dilaksanakan selama dua bulan.

Proses pelaksanaan KKN melibatkan pihakpihak yang terkait, antara lain : Dosen Koordinator KKN, Dosen Pembimbing Lapangan (DPL), Mahasiswa, Ketua Program Studi, dan mitra (masyarakat) di daerah setingkat desa. Dosen
Koordinator KKN bersama tim melakukan survei, pemetaan potensi daerah yang digunakan sebagai lokasi kegiatan. DPL dan mahasiswa masing-masing melakukan survei untuk pengenalan awal daerah yang digunakan untuk pelaksanaan $\mathrm{KKN}$; berkenalan dengan pejabat setempat dan mengetahui lokasi tinggal mahasiswa selama melaksanakan KKN.

Sebelum diberangkatkan mahasiswa diberi pembekalan mengenai mekanisme pelaksanaan KKN dan penyusunan program kerja, penjelasan kelompok, pertemuan dengan DPL, kiat-kiat kreatifitas di masyarakat, pembekalan dan pelatihan 
materi bidang keahlian, potensi daerah dan kondisi sosial budaya daerah tersebut. Pemberangkatan KKN dilakukan bersama-sama (mahasiswa dan DPL) dari kampus menuju lokasi. KKN ISI Surakarta pada tahun 2016 dilaksanakan di dua Kabupaten, yaitu: Kabupaten Wonosobo (terbagi menjadi 6 Kecamatan, 20 Kelurahan/Desa) dan Kabupaten Banjarnegara (terbagi menjadi 5 Kecamatan, 20 Kelurahan/Desa). KKN ISI Surakarta pada tahun 2017 dilaksanakan di Kabupaten Temanggung (tersebar di 12 Kecamatan dan 29 Kelurahan/Desa).

Kegiatan KKN yang ditempatkan di setiap Kelurahan/Desa memiliki koordinator (mahasiswa) yang melaporkan pelaksanaan kegiatan, keberadaan mahasiswa di lokasi dan DPL yang memantau pelaksanaan kegiatan di lapangan. Koordinator melaporkan perkembangan dan permasalahan yang ada di lokasi kepada DPL pada saat DPL melakukan kunjungan. Hal tersebut tentunya menyulitkan DPL dalam memantau perkembangan secara rutin dari hari ke hari, karena kunjungan DPL hanya dilakukan 4 kali selama kegiatan KKN. Koordinator KKN juga kesulitan dalam memantau kegiatan setiap hari karena harus menyesuaikan jadwal kunjungan ke berbagai daerah lokasi KKN.

Saat ini kendala yang dihadapi Koordinator maupun DPL pada kegiatan KKN ISI Surakarta adalah kesulitan dalam memantau kegiatan KKN di lapangan. Pelaporan-pelaporan kegiatan KKN di lapangan selama ini dilakukan dengan komunikasi melalui telepon, SMS (Short Message Service) maupun media sosial. Kelemahan cara tersebut adalah tidak adanya back up informasi-informasi kondisi di lapangan pada saat pelaksanaan KKN. Perangkat yang digunakan mempunyai kemampuan penyimpanan terbatas. Bahkan pada beberapa kasus yang terjadi, data komunikasi sering kali hilang disebabkan kerusakan perangkat.

Beberapa permasalahan tersebut masih menjadi kendala dalam pemantauan kegiatan KKN di ISI Surakarta. Hal serupa juga dialami oleh beberapa perguruan tinggi lain, mengingat masih menggunakan metode yang kurang efektif dalam pemantauan kegiatan KKN. Google Maps merupakan peta digi- tal yang memiliki banyak fitur yang mendukung pemetaan geografis sebuah wilayah, di antaranya: posisi koordinat, marker, dan label yang berisi informasi-informasi pendukung. Pemanfaatan SMS sering digunakan sebagai media komunikasi pertukaran pesan yang berisi informasi. Integrasi Google Maps dan SMS bisa diterapkan untuk pemantauan jarak jauh kegiatan KKN. Informasi marker yang ditampilkan Google Maps selama ini adalah data statis yang tidak berubah. Marker berisi data dinamis yang dapat berubah-ubah setiap saat dari input data SMS (dari user) yang selama ini belum pernah diterapkan.

Untuk itu dilakukan penelitian untuk membuat Aplikasi Sistem Informasi Geografis berbasis Google Maps API Terintegrasi SMS Gateway untuk memantau kegiatan KKN di lapangan secara real time. Aspek yang diteliti antara lain: kebutuhan admin/pengelola $\mathrm{KKN}$, input data dari mahasiswa, output data bagi dosen DPL, konektivitas peta digital dengan data input SMS, aspek teknis data koordinat, kekuatan berbagai sinyal telepon seluler, kecepatan respon sinyal telepon seluler dengan server SMS Gateway, konektivitas data SMS Gateway dengan tampilan marker pada Google Maps. Hasil penelitian ini juga diharapkan dapat menjadi model terapan yang dapat diaplikasikan pada penyelengaraan kegiatan KKN di ISI Surakarta.

\section{Rumusan Penelitian}

Berdasarkan latar belakang yang telah dipaparkan, penelitian ini dirancang atas pertanyaan: bagaimana mewujudkan prototipe sistem pemantau kegiatan $\mathrm{KKN}$, dengan tampilan marker, berisi informasi kegiatan KKN melalui Google Maps yang menggunakan data input SMS dari masing-masing posko KKN.

\section{Urgensi Penelitian}

Penelitian ini menyediakan model rancangan pengelolaan kegiatan $\mathrm{KKN}$ yang dapat memantau lokasi posko dan kegiatan tiap-tiap lokasi, DPL dan daftar peserta KKN secara online dengan tampilan 
peta Google Maps yang memunculkan marker berisi informasi tanggal, jam, lokasi, dan kegiatan-kegiatan. Penelitian ini tidak hanya mengacu pada hal-hal teknis terkait ketersediaan dan kekuatan sinyal di lapangan serta kecepatan respon perangkat dengan aplikasi program, tetapi lebih menekankan pada arsip data kegiatan yang selalu berubah dan dapat dipantau berdasarkan waktu tertentu, sehingga sangat membantu bagi Koordinator dan DPL KKN dalam memantau kegiatan.

\section{Tujuan Penelitian}

Penelitian ini bertujuan:

1. Merancang aplikasi Sistem Informasi Geografis berbasis Google Maps yang terintegrasi dengan SMS untuk memantau kegiatan di lokasi KKN secara real time.

2. Mengusulkan cara baru dalam memantau penyelenggaraan kegiatan $\mathrm{KKN}$, secara luas dan cepat.

\section{KAJIAN LITERATUR}

\section{Sistem Informasi Geografis (SIG)}

Sistem Informasi Geografis (SIG) merupakan sistem informasi yang mengelola data dengan informasi spasial. ${ }^{1}$ SIG memiliki kemampuan dalam membangun, menyimpan, mengelola dan menampilkan informasi geografis. Pada prinsipnya terdapat dua jenis data untuk mendukung SIG, yaitu

\section{a. Data Spasial}

Data spasial merupakan gambaran nyata suatu wilayah di permukaan bumi. Direpresentasikan berupa grafik, peta, gambar dengan format digital. Disimpan dalam bentuk koordinat $\mathrm{x}, \mathrm{y}$ (vektor) atau dalam bentuk image (raster) yang memiliki nilai tertentu. Tampilan peta merupakan objek pada peta yang berhubungan dengan koordinat lintang (Latitude) dan bujur (Longitude).

\section{b. Data Non Spasial (Atribut)}

Data non spasial merupakan data berbentuk tabel. Tabel tersebut berisi informasi yang dimiliki oleh obyek dalam data spasial. Data berbentuk data tabular yang saling terintegrasi dengan data spasial yang ada. Daftar lokasi posko KKN dan nama DPL merupakan data non spasial yang ditampilkan di peta berbentuk info window dari sebuah marker.

\section{SIG Berbasis Web}

SIG berbasis web merupakan gabungan antara desain grafis pemetaan, peta digital dengan analisa geografis, pemrograman komputer, dan database yang saling terhubung menjadi satu bagian web desain dan pemetaan web. Pada akhir tahun 1990an lahir teknologi baru yang dikenal sebagai Internet Map Server. Dengan teknologi ini client dengan mudah menggunakan standar web browser untuk mengirim peta interaktif serta data query melalui Internet.

\section{Google Maps}

Google Maps menyediakan peta globe virtual online yang disediakan oleh Google (http:// maps.google.com). Google Maps menampilkan foto satelit seluruh wilayah di dunia yang dapat digeser dan diperbesar-perkecil citraannya (zoom).

Faktor zoom pada Google Maps yang bernilai maksimal 17 (diperbesar penuh) ke 0 (definisi maksimum). Pada faktor 17, seluruh bumi dalam satu tile di mana $\mathrm{x}=0$ dan $\mathrm{y}=0$. Pada faktor 16 , bumi dibagi dalam bagian $2 \times 2$, di mana $0<=\mathrm{x}<=1$ dan $0<=\mathrm{y}<=1$, dan pada setiap langkah zoom, setiap tile dibagi menjadi 4 bagian. Jadi pada faktor zoom $\mathrm{Z}$, jumlah tile horizontal dan vertikal adalah 2 $\wedge(17-z)$

\section{Aplication Programming Interface (API)}

Perintah, fungsi, dan protokol yang digunakan saat membangun dan mengembangkan perangkat lunak untuk sistem operasi tertentu. Perusahaan besar Google, Facebook, Apple, dan Twitter merupakan perintis penggunaan API, yang memungkinkan orang dan perangkat lain saling terhubung ${ }^{2}$.

\section{Google Maps API}

Google Maps API adalah suatu library yang berbentuk Javascript. Sangat mudah untuk 
menampilkan dan mengintegrasikan Google Maps pada web. Diperlukan pengetahuan HTML, Javascript, dan koneksi internet untuk mengintegrasikan Google Maps ke dalam $w e b^{3}$

\begin{abstract}
. Membangun aplikasi peta digital dengan menggunakan Google Maps API dapat menghemat waktu dan biaya. Tampilan peta sepenuhnya dilakukan oleh Google Maps, sehingga hanya difokuskan pada data-data yang ditampilkan.
\end{abstract}

\section{Sistem Koordinat Google Maps API}

Sistem Koordinat yang digunakan:

a. Nilai-nilai lintang (latitude) dan bujur (longitude) yang mereferensikan sebuah titik unik dunia.

(Google menggunakan standar Sistem Geodesi Dunia WGS84.)

b. Koordinat dunia yang mereferensikan titik unik pada peta

c. Koordinat tile yang mereferensikan tile tertentu pada peta di level zoom yang spesifik.

\section{Jenis Peta}

Google Maps API memiliki 4 jenis pilihan model peta yang disediakan oleh Google:

a. ROADMAP, menampilkan peta biasa, 2 Dimensi.

b. SATELLITE, menampilkan foto satelit.

c. HYBRID, menampilkan gabungan foto satelit dan lapisan diatasnya seperti yang tampil pada ROADMAP (jalan dan nama kota).

d. TERRAIN, menunjukkan relief fisik permukaan bumi dan menunjukkan ketinggian suatu lokasi (gunung dan sungai).

\section{XML}

XML (Extensible Markup Language), merupakan bahasa markup yang dirancang untuk penyampaian informasi melalui website dan dapat juga digunakan untuk pertukaran informasi antar sistem database.

Bahasa markup (markup language) merupakan bahasa pemrograman untuk menandai suatu data. Keuntungan menggunakan XML dapat menyederhanaan aplikasi, dimana database yang ditulis dalam XML dapat diakses di mana saja dan memudahkan aplikasi dalam mengolah data karena dapat menghemat memori. Kemampuan dalam mendefinisikan tag-tag di dalam dokumen XML dapat secara leluasa menerangkan isi data. Berbeda dengan HTML yang digunakan untuk menampilkan data, XML tidak didesain untuk menampilkan data. XML didesain untuk menyimpan dan pertukaran data antar format dari sistem yang tidak kompatibel. Konversi data ke XML dapat mereduksi kompleksitas dan membuat data dapat dibaca oleh aplikasi yang berbeda-beda.

\section{Short Message Service (SMS)}

Short Message Service (SMS) salah satu fasilitas dari teknologi GSM yang memungkinkan mengirim dan menerima pesan singkat berupa text dengan kapasitas maksimal 160 karakter dari Mobile Station (MS) ${ }^{4}$.

Pelayanan SMS membutuhkan sistem SMS Center (SMSC) yang menyimpan dan forward text yang dikirimkan. Saat pesan SMS dikirim dari ponsel (mobile originated) pesan tersebut tidak langsung dikirimkan ke ponsel tujuan ( $\mathrm{mo}$ bile terminated), akan tetapi dikirim terlebih dahulu ke SMS Center (SMSC), baru kemudian pesan tersebut diteruskan ke ponsel tujuan.

\section{Arsitektur Jaringan SMS}

Arsitektur dasar jaringan SMS terdiri dari MO, MSC, SMSC, MT, HLR, VLR. Pada saat SMS dikirim ke nomor tertentu, SMS yang dikirimkan tidak akan langsung dikirimkan ke nomor tersebut, tetapi masuk terlebih dahulu ke SMS Center (SMSC) operator telepon yang digunakan. SMS yang dikirimkan akan masuk ke SMSC ini, kemudian diteruskan ke nomor tujuan SMS tersebut. Bila nomor yang dituju ternyata sedang mati/offline, SMSC ini akan menyimpan SMS tersebut untuk sementara waktu hingga nomor tujuan hidup kembali. Lamanya waktu penyimpanan SMS tergantung dari lamanya waktu yang telah ditetapkan oleh operator untuk menyimpan SMS tersebut. Nomor yang telah menerima SMS akan mengirimkan laporan/report ke SMSC bahwa SMS 
telah diterima. Laporan tersebut diteruskan kembali ke nomor pengirim SMS.

\section{SMS Gateway}

Gateway sering diartikan sebagai jembatan penghubung antar satu sistem dengan sistem lain yang berbeda. Sehingga dapat terjadi suatu pertukaran data antar sistem tersebut. SMS Gateway dapat diartikan sebagai suatu penghubung untuk traffic SMS, baik yang dikirimkan maupun yang diterima. Awalnya, SMS gateway dibutuhkan untuk menjembatani antar SMSC. Hal ini dikarenakan SMSC yang dibangun oleh perusahaan berbeda memiliki protokol komunikasi sendiri, dan protokolprotokol itu sendiri bersifat pribadi.

Seiring berkembangnya jaman, saat ini SMS gateway tidak lagi berfungsi sebagai jembatan penghubung antar SMSC yang berbeda. SMS gateway menjadi jembatan komunikasi yang menghubungkan perangkat komunikasi dengan perangkat komputer, yang menjadikan aktivitas SMS menjadi lebih mudah. Pengertian SMS gateway kemudian lebih mengarah pada sebuah program yang mengkomunikasikan antara sistem operasi komputer, dengan perangkat komunikasi yang terpasang untuk mengirim atau menerima SMS.

\section{SMS Gateway Gammu}

Gammu merupakan sebuah aplikasi yang dapat digunakan untuk mengelola berbagai fungsi pada ponsel, modem dan perangkat sejenisnya ${ }^{5}$. Gammu merupakan salah satu perangkat lunak SMS Gateway yang gratis.

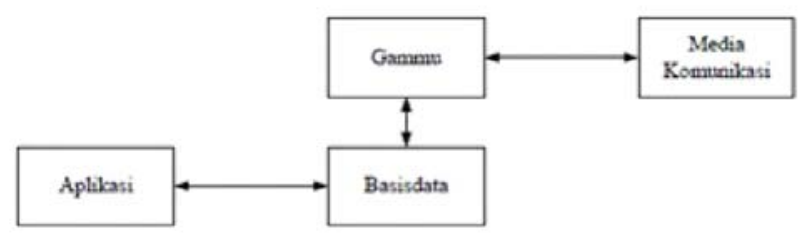

\section{Arsitektur SMS Gateway Gammu}

Banyak perintah yang bisa digunakan dalam aplikasi Gammu. Aplikasi Gammu menyediakan semua perintah standar ponsel yang bisa dijalankan melalui komputer dengan menggabungkan perintah PHP dan database MySQL. Berikut merupakan beberapa fitur SMS Gammu :

a. SMS Broadcast: mengirim pesan SMS langsung ke banyak nomor sekaligus.

b. SMS Terformat: menggunakan SMS dengan format tertentu untuk megirimkan perintah atau informasi.

Contoh : KKN\#LOKASI\#INFORMASI

c. SMS Auto Reply: SMS yang otomatis memberikan balasan berupa informasi setelah ada SMS masuk.

d. SMS Terjadwal: SMS yang secara otomatis (setelah diatur terlebih dahulua) akan terkirim pada saat tertentu (tanggal dan jam tertentu).

Penerapan aplikasi SMS Terformat dan SMS Auto Reply dalam penelitian ini digunakan untuk pembuatan program SIG Pemantau Kegiatan KKN yang terintegrasi dengan Google Maps.

Beberapa penelitian sebelumnya yang membahas tentang Sistem Informasi Geografis yang diimplementasikan pada kegiatan KKN, di antaranya adalah :

Tedy Setiadi, pada penelitiannya yang berjudul "Pengembangan Aplikasi untuk Penentuan Divisi KKN Alternatif berbasis Sistem Informasi Geografis di LPM Universitas Ahmad Dahlan Yogyakarta," 2009, meneliti perancanan perangkat lunak bantu yang mampu menentukan divisi KKN Alternatif berbasis Sistem Informasi Geografis.

Penelitian yang dilakukan oleh Danang Adi Sumarto, berjudul "Sistem Informasi Geografis Monitoring KKN Posdaya Universitas Ahmad Dahlan berbasis Google Maps API," 2014, melakukan perancangan sistem yang menampilkan informasi lokasi dari KKN Posdaya UAD beserta data yang ada secara periodik.

I Ketut Resika Arthana, dalam penelitian yang berjudul "Pengembangan Sistem Informasi Geografis KKN UNDIKSHA Berbasis Teknologi Mobile dan Location Based Service," 2014, mengenai perancangan Sistem Informasi Geografis KKN 
berbasis Google Maps API untuk menampilkan potensi desa lokasi KKN.

Dari ketiga penelitian yang terdahulu, penelitian ini memiliki kesamaan, yaitu perancangan Sistem Informasi Geografis untuk diaplikasikan pada kegiatan KKN. Perbedaan fokus penelitian ini dari penelitian terdahulu adalah penggunaan SMS untuk menampilkan marker pada Google Maps, berisi informasi-informasi yang berhubungan dengan kegiatan pada masing-masing posko KKN. Input data dilakukan secara bervariasi dari tiap posko KKN melalui SMS dengan format khusus.

\section{Road Map Penelitian}

Penelitian ini merupakan penelitian awal yang didorong dari permasalahan pemantauan kegiatan KKN yang kurang optimal, sehingga membuat beberapa pelaksanaan dan realisasi kegiatan di lapangan tidak dapat terlaksana dengan baik. Tujuan penelitian ini adalah membuat prototipe sistem informasi geografis yang terhubung dengan SMS Gateway yang dapat digunakan untuk menampilkan data-data pelaksanaan kegiatan maupun kendala yang ada di lokasi secara real time. Data diperoleh dari SMS yang dikirimkan koordinator tim (mahasiswa) dimasing-masing posko. Diharapkan jika prototipe yang ada dikembangkan dan diimplementasikan, pemantauan dan komunikasi kegiatan KKN di lapangan dapat dilakukan secara cepat. Dampak penelitian ini diharapkan bisa membantu koordinator KKN dalam melakukan evaluasi kegiatan $\mathrm{KKN}$, dan dapat memudahkan DPL dalam melakukan penilaian akhir terhadap pelaksanaan kegiatan.

\section{State of The Arts}

State of the arts dalam penelitian ini adalah bagaimana penelitian ini menjadi model yang dapat dijadikan acuan bagi perguruan tinggi lain dalam menyelenggarakan kegiatan KKN. Komunikasi, pemantauan kegiatan dan proses penilaian bisa dilakukan secara jarak jauh, sehingga tujuan pelaksanaan kegiatan KKN dapat tercapai secara optimal.

\section{METODE PENELITIAN}

Penelitian ini merupakan penelitian eksperimental yang dilakukan melalui beberapa tahapan penelitian, yaitu: pengumpulan data, pengolahan data, perancangan database, perancangan sistem, pengujian sistem dan penarikan kesimpulan. Metode pengumpulan data yang dilakukan dalam penelitian ini menggunakan metode observasi dan wawancara.

\section{Observasi}

Observasi dilakukan dengan mengunjungi lokasi yang digunakan sebagai tempat KKN ISI Surakarta pada tahun 2017, yaitu kabupaten Temanggung ${ }^{6}$. Pengamatan di lapangan bertujuan untuk mendapatkan data koordinat dan data penerimaan sinyal operator telepon seluler GSM yang akan diuji kecepatan responnya terhadap SMS pengirim ke mesin penerima SMS, yaitu SMS Gateway. Data koordinat didapatkan dengan menggunakan GPS, sedangkan untuk mengetahui ketersediaan sinyal pada masing-masing lokasi digunakan perangkat lunak Network Cell Info berbasis OS Android yang diinstal pada telepon seluler. Pengecekan sinyal dilakukan pada tiga operator telepon seluler GSM yang memiliki cakupan jaringan $4 \mathrm{G}$ di Indonesia, antara lain: Telkomsel, Indosat dan XL.?

\section{Lokasi Penelitian}

Lokasi penelitian dilakukan pada 29 desa dari 12 kecamatan di kabupaten Temanggung.

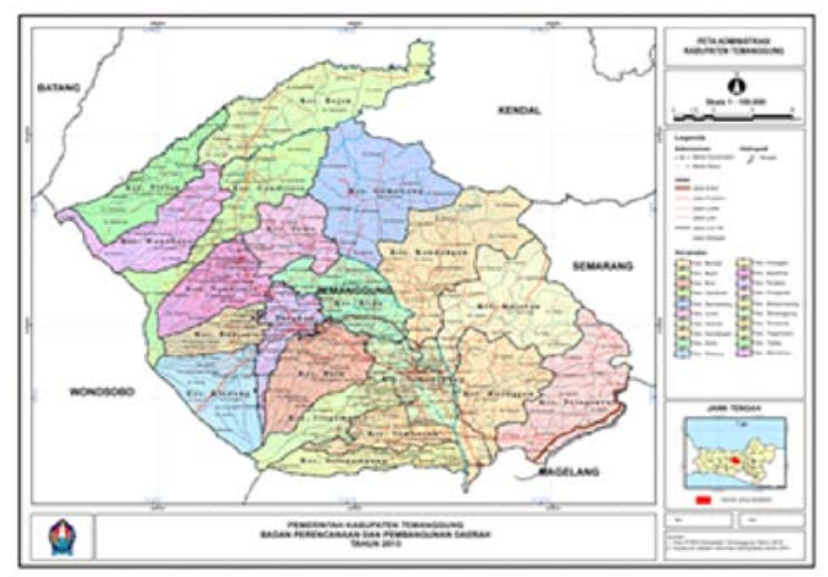

Peta Administrasi Kab. Temanggung ${ }^{8}$

Survei lapangan dan pengambilan data dilakukan di beberpa desa, antara lain: (1) desa Campursari, Pagergunung, Tegalrejo, dan Gondosuli di kecamatan Bulu, (2) desa Kedu, Mergowati, dan Kundisari di kecamatan Kedu, (3) desa Gedongsari, 
dan Sukomarto di kecamatan Jumo, (4) desa Geblog, Tegowanuh, dan Gandulan di kecamatan Kaloran, (5) desa Jragan, Gandu, dan Menggoro di kecamatan Tembarak, (6) desa Madureso di kecamatan Temanggung, (7) desa Ngropoh, Sanggrahan, dan Legoksari di kecamatan Kranggan, (8) desa Legoksari, dan Tlilir di kecamatan Tlogomulyo, (9) desa Caruban, Gesing, dan Kembangsari di kecamatan Kandangan, (10) desa Purbosari, dan Tegalrejo di kecamatan Ngadirejo, (11) desa Kledung dan Tlahap di kecamatan Kledung, (12) desa Parakan Wetan dan Parakan Kauman di kecamatan Parakan.

Hasil survei data di lapangan didapatkan koordinat dalam bentuk tabel berikut :

\section{Tabel Data Lokasi dan Koordinat ${ }^{9}$}

\begin{tabular}{|r|l|l|l|c|c|}
\hline No & Kecamatan & No & Desa & Latifude & Longitude \\
\hline 1 & Bulu & 1 & Campursari & -7.283352 & 110.120896 \\
\hline & & 2 & Pagergumung & -7.333351 & 110.094099 \\
\hline & & 3 & Tegalrejo & -7.257457 & 110.016680 \\
\hline & & 4 & Gondosuli & -7.302636 & 110.107157 \\
\hline 2 & Kedu & 5 & Kedu & -7.258290 & 110.134302 \\
\hline & & 6 & Mergowati & -7.261048 & 110.137109 \\
\hline & & 7 & Kundisari & -7.261426 & 110.125197 \\
\hline 3 & Jumo & 8 & Gedongsan & -7.230873 & 110.119240 \\
\hline & & 9 & Sukomarto & -7.237616 & 110.084020 \\
\hline 4 & Kaloran & 10 & Geblog & -7.277469 & 110.220672 \\
\hline & & 11 & Tegowanuh & -7.293286 & 110.202630 \\
\hline & & 12 & Gandulan & -7.304547 & 110.204119 \\
\hline 5 & Tembarak & 13 & Jragan & -7.342867 & 110.153488 \\
\hline & & 14 & Gandu & -7.357764 & 110.143065 \\
\hline & & 15 & Menggoro & -7.359355 & 110.180464 \\
\hline 6 & Temanggung & 16 & Madureso & -7.336012 & 110.198162 \\
\hline 7 & Kranggan & 17 & Ngropoh & -7.345503 & 110.241521 \\
\hline & & 18 & Sanggrahan & -7.328409 & 110.220672 \\
\hline 8 & Tlogomulyo & 19 & Legoksari & -7.362920 & 110.114773 \\
\hline & & 20 & Tlilir & -7.356629 & 110.132813 \\
\hline 9 & Kandangan & 21 & Caruban & -7.264409 & 110.178975 \\
\hline & & 22 & Gesing & -7.236008 & 110.181782 \\
\hline & & 23 & Kembangsari & -7.242369 & 110.202630 \\
\hline 10 & Ngadirejo & 24 & Purbosari & -7.246554 & 110.031394 \\
\hline & & 25 & Tegalrejo & -7.257288 & 110.016678 \\
\hline 11 & Kledung & 26 & Kledung & -7.328165 & 110.056876 \\
\hline & & 27 & Tlahap & -7.326843 & 110.029905 \\
\hline 12 & Parakan & 28 & Parakan Wetan & -7.281483 & 110.106011 \\
\hline & & 29 & Parakan Kauman & -7.286634 & 110.093928 \\
\hline
\end{tabular}

\section{Wawancara}

Wawancara dilakukan kepada penentu kebijakan pelaksanaan KKN, yaitu kepala Pengabdian Kepada Masyarakat (PKM), pengelola kegiatan $\mathrm{KKN}$ dan dosen-dosen yang pernah bertugas sebagai DPL KKN. Materi pertanyaan yang diajukan antara lain mengenai pengalamanpengalaman tentang pelaksanaan, pengelolaan, dan pemantauan kegiatan $\mathrm{KKN}$ di lapangan, hingga pendalaman-pendalaman terkait dengan kasus maupun situasi di lapangan. Terutama hambatanhambatan yang dialami dan cara mengatasi hambatan tersebut.

\section{Alat Penelitian}

Alat-alat yang digunakan dalam penelitian ini adalah :

\section{Hardware (Perangkat Keras)}

Notebook: Processor Core I3, RAM 16 GB, Hardisk 80 GB untuk menjalankan perangkat lunak XAMPP (Apache, PHP,MySQL Server), Gammu dan editor Notepad ++. Modem GSM WAVECOM FASTRACK 1306 B untuk SMS Gateway, dan modem GSM \& CDMA untuk koneksi internet.

\section{Software (Perangkat Lunak)}

a. XAMPP (Apache web server, PHP dan MySQL database server).

b. Gammu untuk manajemen SMS Gateway.

c. Google Maps API untuk menampilkan peta, marker dan info window.

d. XML untuk menjembatani database dari format PHP ke dalam bahasa Java Script untuk tampilan marker dan info window pada Google Maps.

e. Notepad ++ digunakan untuk pemrograman web.

f. Browser Internet Explorer, Mozilla Firefox dan Google Chrome, Safari Netscape, dan Opera digunakan untuk pengujian sistem.

\section{Bahan Penelitian}

Bahan yang digunakan dalam penelitian ini antara lain :

1. Aplikasi Cell Network Info, digunakan untuk melakukan pengecekan sinyal operator telepon seluler di lapangan. Aplikasi tersebut dapat mengetahui besarnya sinyal yang ditunjukkan dalam bentuk RSSI dan ASU. RSSI (Received Signal Strength Indicator), yaitu kuat sinyal yang diterima pada frekuensi tertentu termasuk noise dan interferensi yang dinyatakan dalam satuan $(\mathrm{dBm})$. Sedangkan ASU = Arbitrary Strength Unit (ASU) merupakan kuat sinyal yang diterima oleh perangkat telepon seluler. 
2. Data lokasi dan koordinat (latitude) dan (longitude) digunakan sebagai acuan penempatan marker pada peta sesuai lokasi posko KKN.

3. Data SMS yang masuk dalam tabel inbox di $\mathrm{d} a-$ tabase, dengan mengunakan format: KKN\#LOKASI\#INFORMASI dipisah dan dibandingkan dengan data lokasi posko yang disimpan dalam tabel location.

Penelitian dilakukan dengan membuat suatu rancangan sistem yang dapat diimplementasikan menjadi Sistem Informasi Geografis menggunakan Google Maps dari perangkat mobile berupa data SMS terformat. Rancangan ini dibuat untuk memberikan informasi geografis nama posko $\mathrm{KKN}$, lokasi posko KKN, waktu pengiriman dan status mahasiswa serta informasi kegiatan di posko KKN. Langkah-langkah penelitian yang dilakukan sebagai berikut :

1. Mengumpulkan data lokasi dan koordinat posko $\mathrm{KKN}$, yang tersebar di wilayah kabupaten Temanggung sebagai data awal penelitian.

2. Menganalisis proses bisnis yang diterapkan dari hasil pengumpulan data sehingga diperoleh data lokasi dan koordinat posko KKN di wilayah kabupaten Temanggung.

3. Melakukan perancangan sistem.

Analisis sistem dibuat model dalam satu bentuk rancangan yang mengacu pada teori UML (Unified Modelling Language). Entitas yang terlibat dibuat model menjadi aktor dan aktifitas yang terjadi dibuat model ke dalam bentuk use case; proses aliran data dibuat model dalam bentuk DFD; entitas yang terkait dan atribut serta operasinya dibuat model dalam bentuk Entity Relationship Diagram (ERD).

\section{Perancangan Sistem}

1. Arsitektur Sistem:

Sistem Informasi Geografis (SIG) yang dibangun memberikan informasi nama posko, lokasi, DPL, jumlah mahasiswa dan kegiatan di posko KKN. Sistem berbasis client-server dengan data terpusat pada web server dan database server yang juga berfungsi sebagai SMS Gateway server. Arsitektur sistem yang dibangun, dijelaskan pada gambar berikut :

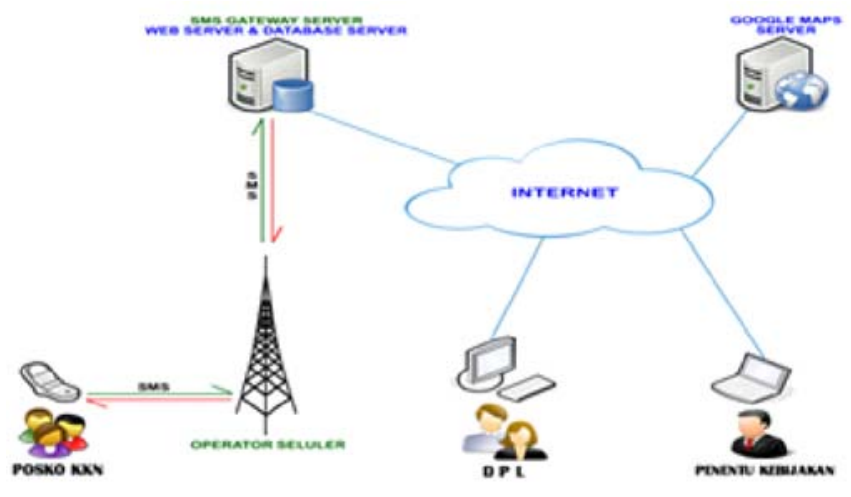

Arsitektur SIG untuk Posko KKN Proses Sistem Pemantau Kegiatan KKN

Mahasiswa yang berada di posko KKN mengirimkan SMS menggunakan format KKN\#LOKASI\#INFORMASI, diterima oleh SMS Gateway yang masuk dalam tabel inbox di database. Server melakukan pengecekan apakah format SMS yang dikirimkan benar atau salah. Jika format SMS benar, maka server secara otomatis mengirimkan SMS balasan yang menyatakan bahwa SMS yang telah dikirim formatnya benar. Jika format SMS salah, maka server secara otomatis mengirimkan SMS balasan yang menyatakan bahwa format SMS yang dikirim salah. Server secara otomatis mengirimkan contoh format SMS yang benar. Selanjutnya server mencocokkan isi database location yang berisi lokasi, DPL dan koordinat dengan menggunakan web service (XML). Kemudian Google Maps menampilkan marker dan info window pada peta. Pada gambar berikut digambarkan Proses SIG Pemantau Kegiatan KKN.

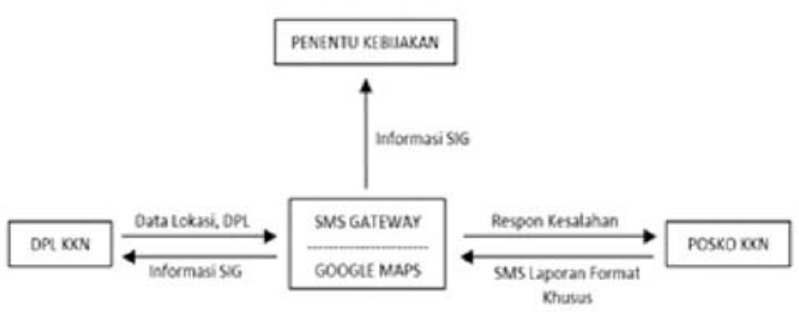

\section{Proses Sistem Pemantau Kegiatan KKN}

\section{Diagram Use Case}

Use case mendeskripsikan perilaku sistem dalam menanggapi permintaan yang berasal dari luar sistem itu. Sebuah use case menggambarkan "yang" 
bisa melakukan "apa" dengan sistem yang bersangkutan. Use case menggambarkan interaksi antara satu atau lebih aktor dan sistem itu sendiri. Digambarkan sebagai urutan langkah-langkah sederhana. Use case untuk perancangan sistem server dapat dilihat pada gambar berikut :

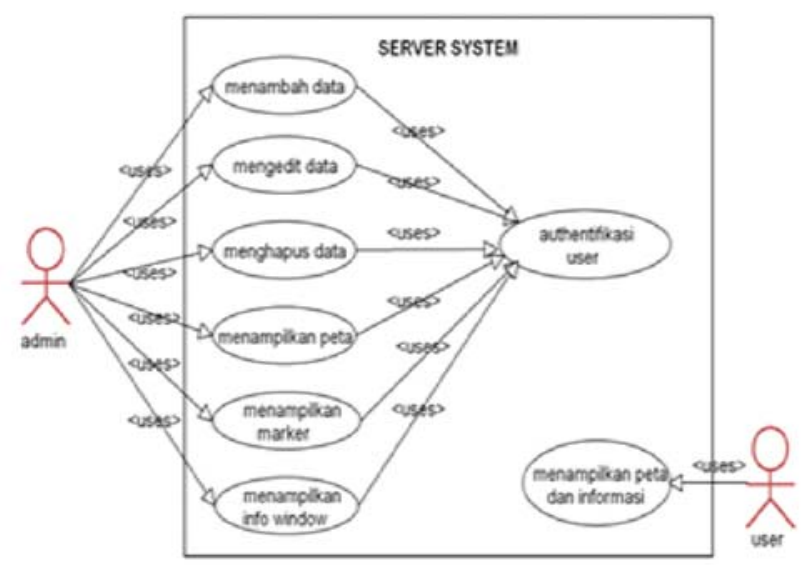

Use Case Server

Gambar Use Case Server menjelaskan bahwa aplikasi server mempunyai 2 entitas aktor, yaitu admin dan user. Admin adalah pengguna level tertinggi yang mampu mengakses secara penuh terhadap aplikasi yang berinteraksi dengan use case: manambah data, mengedit data, menghapus data, menampilkan peta, menampilkan marker, menampilkan info window. User hanya dapat menampilkan informasi tampilan peta, menampilkan marker dan menampilkan info window. Untuk lebih jelas mengenai akses client terhadap aplikasi dapat dilihat pada gambar berikut :

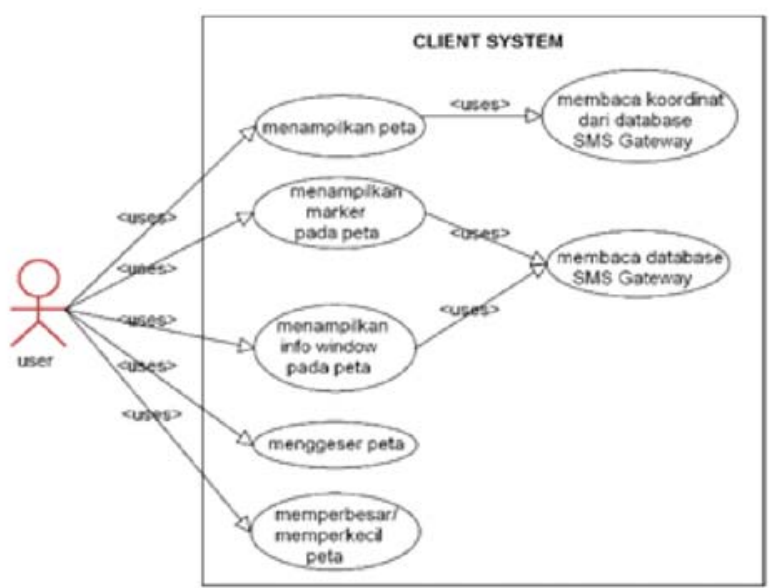

User dapat mengakses tampilan peta, yang koordinatnya diunduh dari database server SMS Gateway dan web SIG, untuk menampilkan marker, info window, melakukan penggeseran peta, memperbesar/memperkecil tampilan peta.

\section{Diagram Konteks}

Diagram Konteks ini menggambarkan penjabaran sistem secara umum, proses request dan respon yang terjadi dalam sistem dalam mengakses aplikasi SIG. Gambar berikut menjelaskan cara kerja pengaksesan aplikasi SIG.

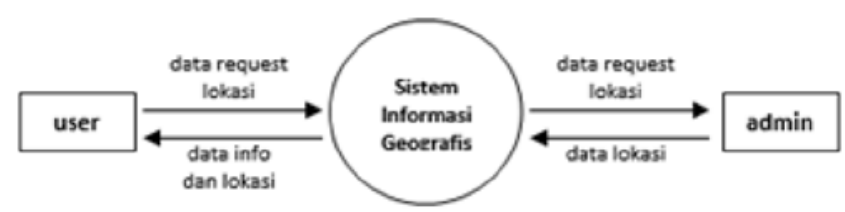

\section{Diagram Konteks Aplikasi SIG}

User mengakses melalui tampilan browser, melakukan request data spasial dan non spasial ke server. Setelah mendapat respon dari server, data dikembalikan ke client dan menampilkan peta dan data yang diminta.

\section{Data Flow Diagram (DFD)}

Data Flow Diagram (DFD) dapat digunakan untuk menggambarkan aliran data yang mengalir dalam sistem.

\section{a. DFD Level 0}

DFD Level 0 merupakan penjabaran yang lebih rinci dari diagram konteks. Dalam sistem tersebut, admin melakukan input data referensi peta, dan melakukan pengolahan data.

Peta berbentuk marker dan info window menampilkan marker dan info window yang berisi informasi posko dan lokasi yang ditampilkan. User melakukan request dengan memasukkan waktu pengiriman. Sistem kemudian akan menampilkan dalam bentuk marker dan info window. DFD Level 0 dijelaskkan pada gambar berikut :

\section{Use Case User}




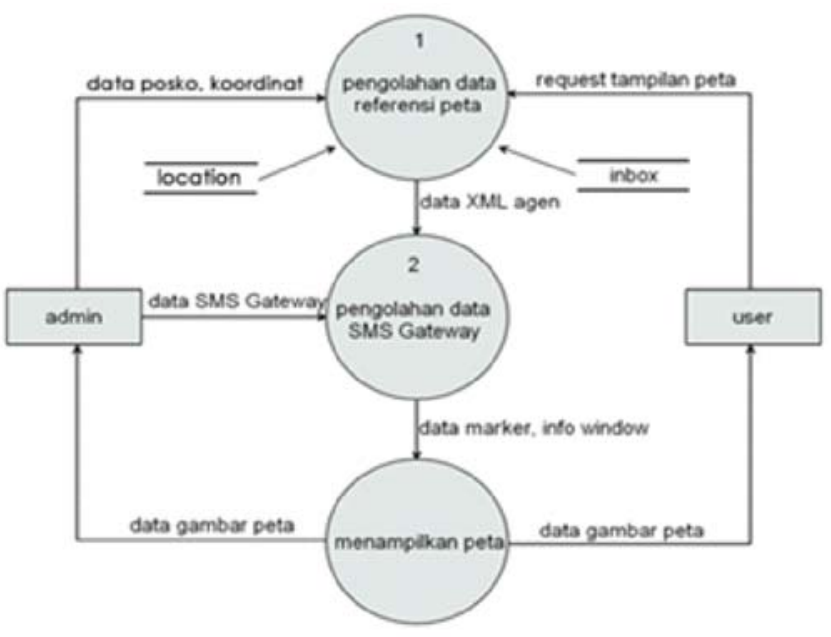

DFD Level 0

\section{b. DFD Level 1}

DFD Level 1 pengolahan data referensi peta merupakan penjabaran dari DFD Level 0 pada proses nomor 1 . Pengolahan data data spasial dan data non spasial peta dengan memasukkan data yang akan digunakan di dalam sistem oleh admin dan permintaan data yang dilakukan oleh user.

Admin memasukkan data posko, lokasi dan koordinat yang kemudian tersimpan dalam tabel location. Sedangkan user memasukkan data request untuk menampilkan peta dengan marker dan info window. Pada gambar berikut ini menggambarkan proses pengolahan data referensi peta yang dilakukan oleh admin.

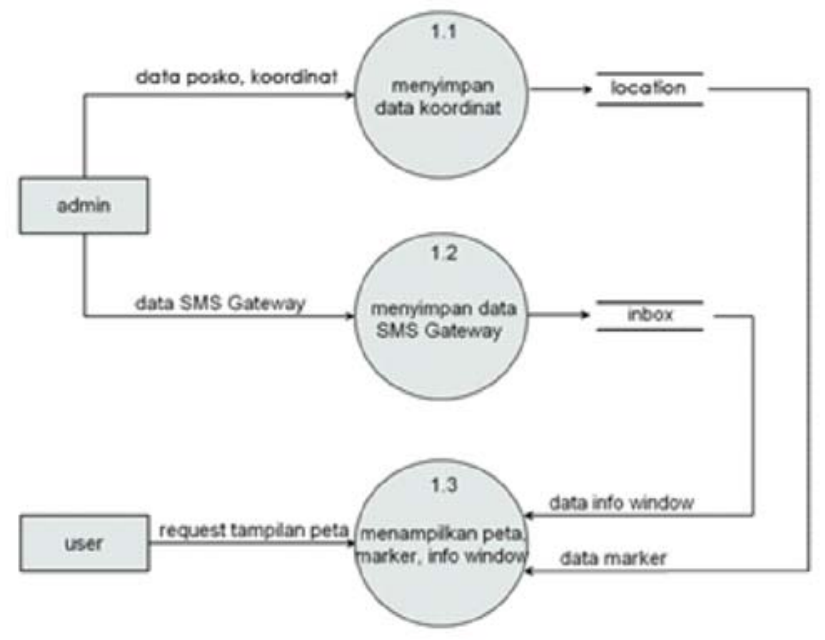

DFD Level 1

\section{Rancangan Flowchart Sistem}

Flowchart sistem digunakan untuk menggambarkan alur logika bagaimana sistem berjalan, merupakan proses request user ke sistem.

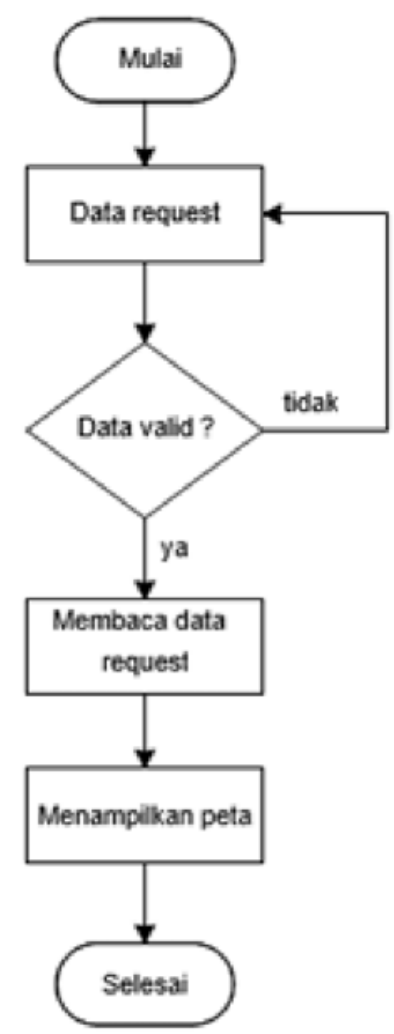

\section{Flowchart Sistem}

\section{Metode Pengujian Sistem}

Setelah perancangan sistem, selanjutnya dilakukan pengujian terhadap sistem. Pengujian yang dilakukan meliputi pengujian input/output testing (performance system).

Pengujian dilakukan untuk menemukan apakah ada program yang tidak berjalan sesuai dengan spesifikasi (fungsional) sistem. Untuk menemukan semua kesalahan, maka pengujian dilakukan dengan menggunakan berbagai kemungkinan sebagai input. Input yang dimasukkan tidak hanya input valid, tetapi juga input kombinasi yang tidak valid. Sistem diuji coba dengan melakukan proses request data untuk menampilkan peta berdasarkan tanggal, bulan dan tahun tertentu. Request data disimulasikan pada sistem untuk membuktikan bahwa sistem dapat berjalan dengan baik. 


\section{HASIL DAN PEMBAHASAN}

\section{Hasil Penelitian}

Hasil penelitian berupa SIG client-server yang tediri dari satu aplikasi server berbasis web yang dapat menampilkan marker dan info window dari data SMS Gateway yang dikirim oleh tiap posko di lokasi KKN yang berbeda.

Pada sisi server, sistem melakukan filter data SMS yang berisi informasi posko, lokasi dan informasi kegiatan posko KKN dengan perintah explode pada PHP. Metode tersebut memisahkan karakter yang mengandung karakter tertentu sesuai tabel location (berisi data tentang: nama posko, lokasi, DPL dan koordinat). Dengan bantuan XML data pada tabel datamarker yang berisi informasi posko, koordinat dan data inbox dari SMS akan ditampilkan dalam bentuk marker dan info window pada Google Maps.

Pada sisi client, user dapat menampilkan peta dengan metode Real Time dan pilihan (tanggal, bulan dan tahun) yang dapat ditentukan sendiri. User dapat menampilkan marker, info window, menggeser peta, memperkecil tampilan peta dan memperbesar tampilan peta.

\section{Filter Data Non Spasial Peta}

SIG yang dibangun memerlukan data peta berupa data spasial yang akan disimpan dalam database MySQL di sisi server. Terdapat beberapa jenis data yang difilter untuk menampilkan informasi pada peta.

1. Data SMS Gateway diperlukan sebagai filter data SMS untuk format yang digunakan dalam SIG Pemantau Kegiatan KKN, Contoh: KKN\#LOKASI\#INFORMASI. Jika SMS yang dikirimkan oleh $u$ ser tidak sesuai dengan format yang sudah ditentukan, maka SMS tidak diproses dan data tidak ditampilkan di peta.

2. Data posko dari tabel location berisi informasi mengenai posko, DPL dan koordinat. Tabel location akan diakses jika SMS yang dikirimkan sesuai dengan format yang sudah ditentukan. Selanjutnya program akan melakukan proses explode yang hasilnya akan dibandingkan dengan data yang ada dengan data yang ada pada tabel locaion. Jika data yang dibandingkan cocok, program secara otomatis akan mengisi data pada tabel datamarkers dalam bentuk XML. Data berisi informasi mengenai posko, lokasi, DPL, informasi kegiatan di posko KKN, dan waktu pengiriman SMS.

\section{Halaman Login}

Pada halaman utama, saat pertama kali sistem dijalankan, akan ditanyakan userID dan password. Halaman ini tampil sebagai security bagi pengguna yang berhak mengakses server. Terdapat 2 jenis hak akses yang dibolehkan masuk ke dalam sistem, yaitu: Admin dan User. Gambar berikut ini merupakan tampilan halaman Login dari Aplikasi SIG Pemantau Kegiatan KKN.

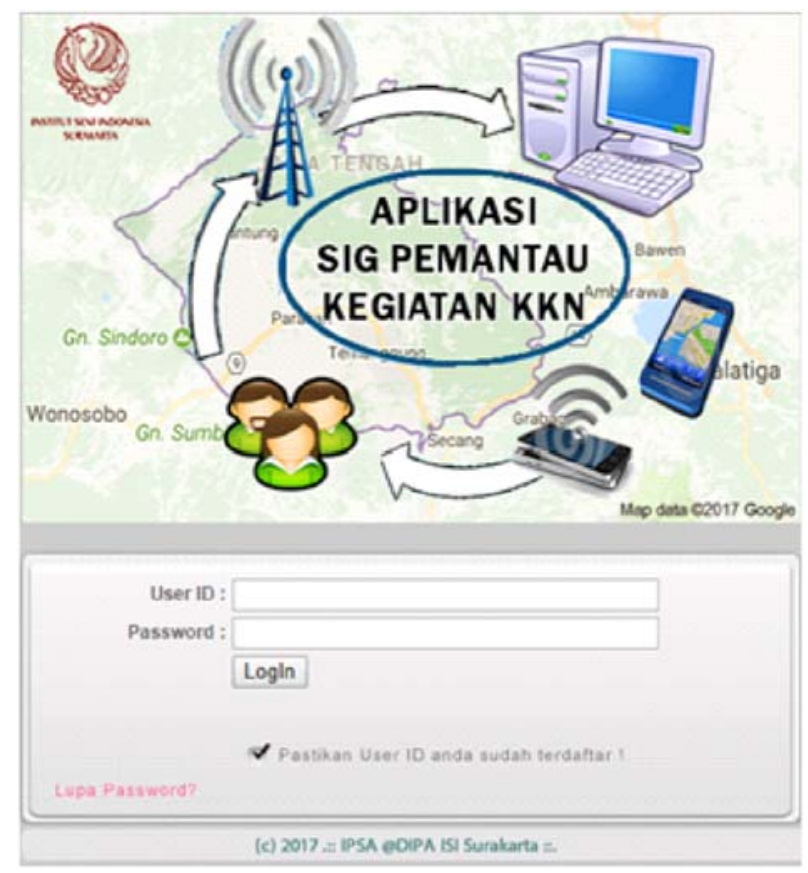

Halaman Login

\section{Halaman Admin}

Halaman ini merupakan halaman utama admin setelah proses login dilakukan. 


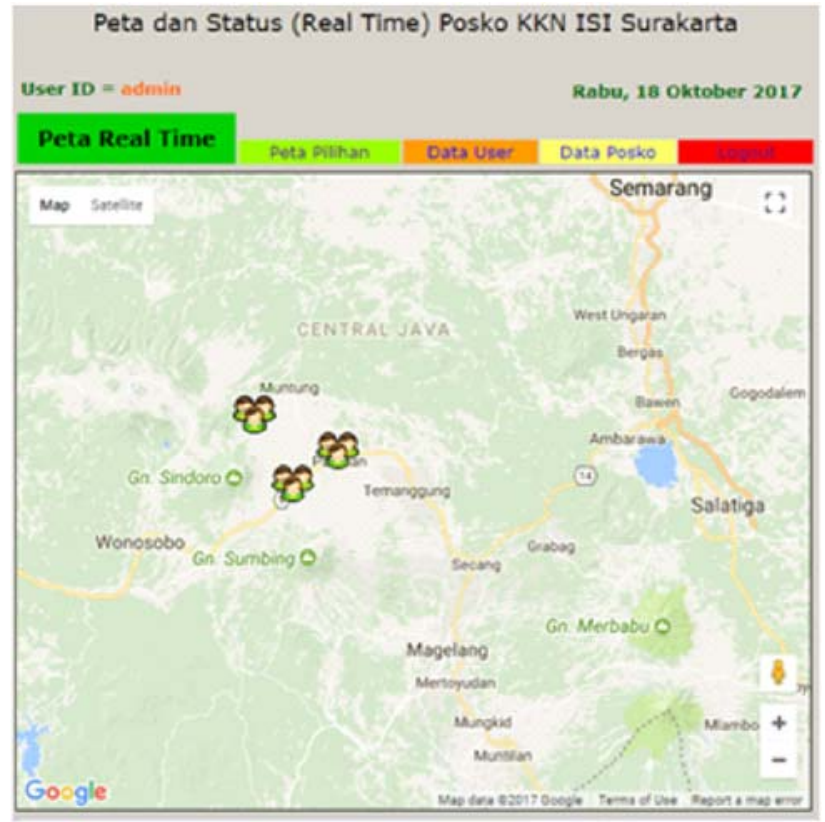

\section{Halaman Utama Admin}

Pada Halaman Utama Admin, terdapat menu utama yang digunakan untuk mengakses menu-menu yang lain. Menu utama yang ada pada halaman ini terdiri dari:

\section{Menu Peta Real Time.}

Tampilan Peta Real Time dengan marker dan info window menampilkan status Peta dengan kondisi terkini. Gambar berikut menunjukkan tampilan Halaman Utama Admin, Menu Peta Real Time, terdapat beberapa marker. Jika diklik akan memunculkan menu info window berisi informasi nama: posko desa, kecamatan (font Bold/tebal); informasi nama DPL (font Underline/garis bawah); informasi kegiatan posko (berisi status jumlah mahasiswa yang berada di posko); kegiatan KKN bersama masyarakat; dan informasi waktu yang menunjukkan tanggal dengan format "hari/bulan/ tahun" (misalnya: 18/10/2017), serta jam pada waktu SMS dikirimkan dari posko KKN dengan format "jam:menit:detik" (misalnya: 09:10:46). Informasi marker dan info window di lokasi akan berbeda sesuai lokasi posko, jumlah mahasiswa di posko dan kegiatan serta waktu pengiriman informasi (menggunakan SMS).

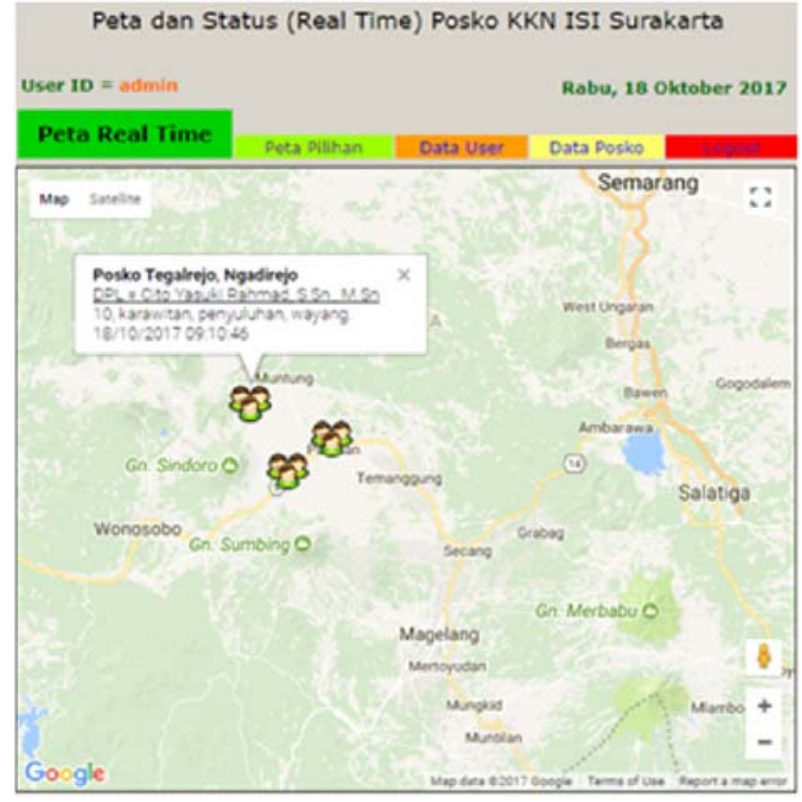

Marker dan Info Window Peta Real Time

2. Menu Peta Pilihan.

Tampilan Peta Pilihan dengan marker dan info window yang menampilkan Peta dengan pilihan tanggal, bulan dan tahun tertentu.

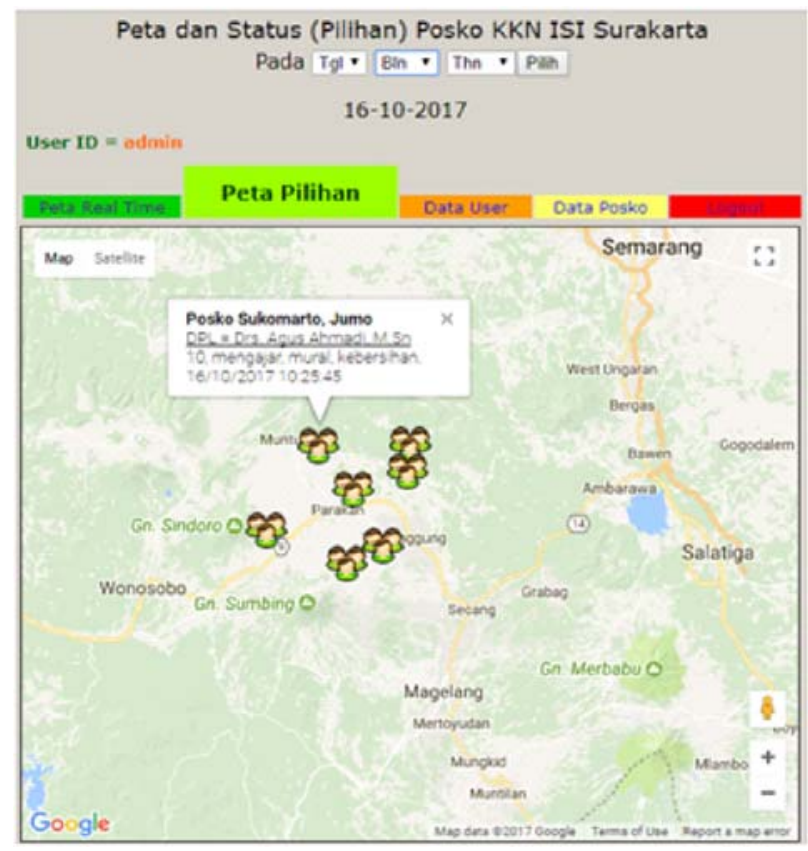

\section{Marker dan Info Window Peta Real Time}

Tampilan Peta Pilihan ini berfungsi untuk mengetahui informasi posko pada waktu yang dapat ditentukan dengan menekan menu tanggal (Tgl) yang berisi angka 1 sampai 28/29/30/31 sesuai banyaknya hari dalam bulan tertentu. Sistem juga 
dapat mendeteksi tahun kabisat yang berdampak pada jumlah hari pada bulan Februari. Menu bulan (Bln) berisi bulan Januari (Jan), Februari (Feb), Maret (Mar), April (Apr), Mei, Juni(Jun), Juli (Jul), Agustus (Ags), September (Sep), Oktober (Okt), Nopember (Nop), dan Desember (Des). Menu tahun (Thn) dalam program ini diatur mulai tahun 2017, jika tahun bertambah, maka sistem secara otomatis menambahkan tahun sesuai jumlahnya.

\section{Menu Data User}

Menu ini digunakan untuk menambah, mengedit dan menghapus data $U$ ser, seperti ditunjukkan pada gambar berikut :

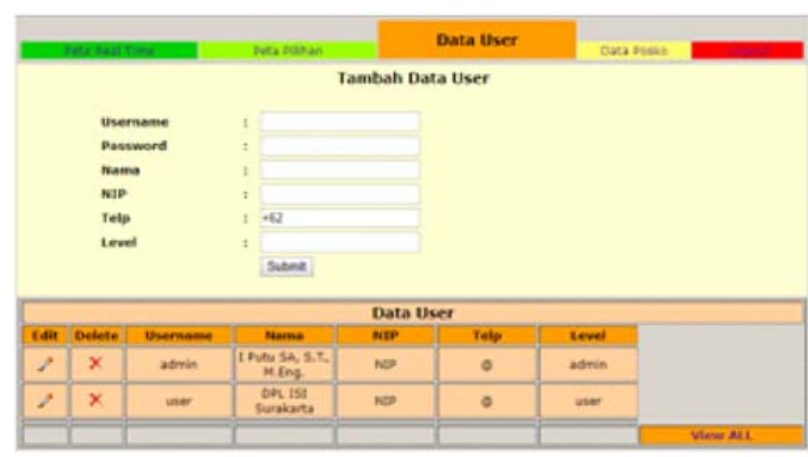

\section{Menu Data User}

\section{Menu Data Posko}

Menu ini digunakan untuk menambah, mengedit dan manghapus data posko (nama posko, lokasi, DPL dan koordinat).

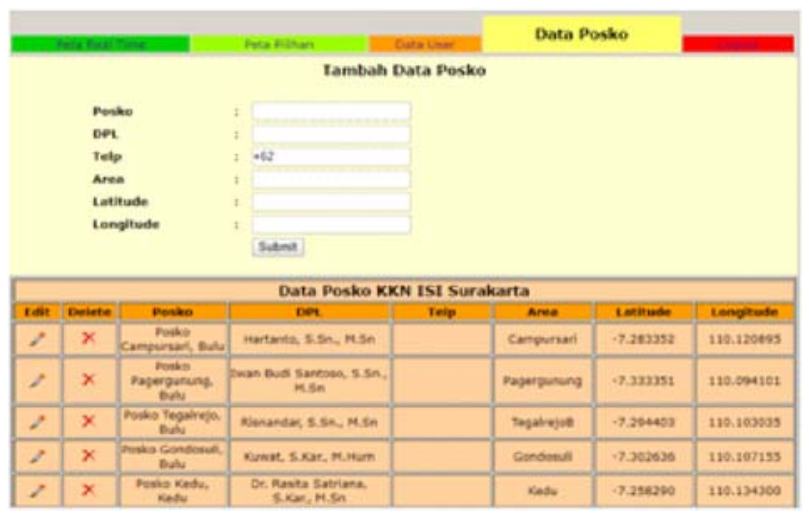

\section{Menu Data Posko}

\section{Logout}

Menu ini digunakan untuk keluar dari sistem Aplikasi SIG Pemantau KKN.

\section{Halaman User}

Halaman User hanya memiliki tampilan menu Peta Real Time, menu Peta Pilihan (tanggal, bulan dan tahun) dan Logout.

\section{Analisis Kemampuan Sistem}

Kemampuan sistem dianalisis dengan mengacu pada rancangan sistem, yang dirancang untuk menampilkan peta. Dari spesifikasi kebutuhan dan tahapan perancangan sistem diperoleh hasil kemampuan yang bisa dilakukan oleh sistem baik di sisi Server dan Client. Analisis kemampuan sistem dapat dilihat pada Tabel berikut :

\section{Tabel Analisis Kemampuan Sistem}

\begin{tabular}{|c|c|}
\hline Aplikasi & Kemampuan \\
\hline Aplikasi Server & $\begin{array}{l}\text { 1. meazolah data spasial (kocrdinat). } \\
\text { 2. meagolah data son spasial uatuk: } \\
\text { a. mengolah data peta (meanbah dan menghapus marker). } \\
\text { b. mengolah data dan informasi (edit, tambah, hapus data info } \\
\text { window). }\end{array}$ \\
\hline Aplikasi Client & $\begin{array}{l}\text { 1. melakukan permintaan data spasial dan aca spasial ke server serta } \\
\text { meaerima respon dari senver. } \\
\text { 2. measmpilkan peta. } \\
\text { 3. meayediakan fasilitas zoom. } \\
\text { 4. meavediakan perreseras peta. }\end{array}$ \\
\hline
\end{tabular}

\section{Pengujian pada bandwidth $156 \mathrm{Kbps}$}

Pada bandwidth 153 Kbps, browser Google Chrome, lebih responsif dalam menampilkan peta, yaitu 0,9 detik dan 0,54 detik untuk menampilkan marker. Sedangkan browser Internet Explorer tidak dapat menampilkan marker.

\section{Pengujian pada bandwidth 512 Kbps}

Pada bandwidth 512 Kbps browser Opera lebih responsif dalam menampilkan peta, yaitu 0,63 detik dan browser Google Chrome lebih responsif menampilkan marker, yaitu 1,71 detik. Browser Internet Explorer masih tidak dapat menampilkan marker.

\section{Pengujian pada bandwidth2240 Kbps}

Pada bandwidth $2240 \mathrm{Kbps}$, browser Opera lebih responsif dalam menampilkan peta, yaitu 0,41 detik dan membutuhkan waktu 1,35 detik untuk menampilkan marker. Pada bandwidth 2240 Kbps, browser Internet Explorer dapat menampilkan marker.

Pengujian pada browser versi lama dan terbaru sengaja dilakukan, untuk mengetahui respon dari 
browser. Apakah program mampu berjalan pada browser versi lama atau tidak, ternyata setelah dilakukan pengujian browser lama masih bisa menjalankan aplikasi.

\section{Kelebihan dan Kekurangan Sistem}

Sistem yang dibangun dengan memiliki beberapa kelebihan dan kekurangan :

\section{Kelebihan}

a. Peta mudah diakses dimana saja, selama client terkoneksi dengan internet.

b. Data terpusat pada satu server.

c. Biaya SMS yang murah untuk merealisasikan sistem.

\section{Kekurangan}

a. Sistem harus selalu terkoneksi dengan Internet untuk dapat menampilkan peta dari Google Maps.

b. Memerlukan bandwidth yang besar untuk tampilan Google Maps.

\section{KESIMPULAN}

Setelah dilakukan serangkaian pengujian dan analisis dalam penelitian ini, maka dapat diambil kesimpulan sebagai berikut:

1. Format SMS yang paling efisien digunakan memisahkan informasi adalah: KKN, LOKASI, INFORMASI. Berfungsi memisahkan data posko, lokasi dan informasi kegiatan di masing-masing posko KKN.

2. Aplikasi SIG Pemantau Kegitatan KKN yang dibangun dapat menampilkan peta dengan marker (untuk menentukan posisi) dan info window (berisi informasi posko, DPL, informasi) dengan SMS Gateway. Data SMS yang masuk ke dalam tabel inbox difilter menggunakan perintah explode yang memisahkan informasi SMS berisi data LOKASI dan INFORMASI. Data yang sudah difilter kemudian dicocokkan dengan tabel location yang berisi informasi posko, lokasi, DPL dan koordinat. Program XML melakukan proses konversi dari data tabel location untuk diisi ke tabel datamarkers. Selanjutnya dapat dieksekusi melalui program datalokasi.php. Data XML tersebut yang selanjutnya digunakan untuk menampilkan informasi pada marker yang memunculkan info window.

Beberapa saran yang dapat digunakan untuk penelitian selanjutnya :

1. Pemantauan kegiatan KKN sebaiknya tidak hanya dilakukan ditingkat mahasiswa peserta $\mathrm{KKN}$ yang berada di posko. Ada baiknya juga dilakukan pada DPL untuk memantau kunjungan di lokasi KKN beserta informasi kendala yang ada di lapangan.

2. Tampilan marker dan info window dengan informasi yang bersifat interaktif.

3. Program dapat dikembangkan dengan mengintegrasikan Decission Support System.

\section{REFERENSI}

\section{DaftarAcuan :}

Abdul Kadir, 2008. Dasar Pemograman Web Dinamis Menggunakan PHP. Penerbit : Andi, Yogyakarta.

Daniel Jacobson, Greg Brail \& Dan Woods, 2012. APIs: A Strategy Guide. Penerbit :O'reilly, USA),

Eddy Prahasta, 2009. Sistem Informasi Geografis : Konsep-konsep Dasar (Perspektif Geodesi \& Geomatika). Penerbit : Informatika, Bandung.

Riyanto, 2009.Pengembangan Aplikasi Sistem Informasi Geografis, Penerbit : Gava Media, Jakarta.

Sugiyono, 2016, Metode Penelitian Kuantitatif, Kualitatif, dan R\&D. Bandung. Penerbit : Alfabeta.

\section{Artikel Jurnal :}

Danang Adi Sumarto, 2014. Sistem Informasi Geografis Monitoring KKN Posdaya Universitas Ahmad Dahlan Berbasis Google Maps API, Jurnal Informatika, 
Vol 2, No2, UAD, Yogyakarta.

I Ketut Resika Arthana, 2014. Pengembangan Sistem Informasi Geografis Kuliah Kerja Nyata (KKN) UNDIKSHA Berbasis Teknologi Mobile dan Location Based Service, Penelitian DIPA UNDIKHSA, Singaraja, Bali.

Tedy Setiadi, 2009. Pengembangan Aplikasi untuk Penentuan Divisi KKN Alternatif Berbasis Sistem Informasi Geografis di LPM Universitas Ahmad Dahlan Yogyakarta, Jurnal Informatika, Vol 3, No. 1, UAD, Yogyakarta.

\section{Daftar Narasumber :}

Cito Yasuki Rahmad, 39 tahun, Surakarta, Ketua Jurusan Seni Media Rekam, Fakultas Seni Rupa dan Desain ISI Surakarta.

Donie Fadjar Kurniawan, 45 tahun, Surakarta, Dosen Prodi Televisi dan Film ISI Surakarta.

H. Dwi Wahyudiarto, 56 tahun, Surakarta, Wakil Dekan I, Fakultas Seni Pertunjukan, ISI Surakarta.

Sri Hadi, 58 tahun, Surakarta, Kepala Pusat Pengabdian LPPM, ISI Surakarta

\section{Artikel Internet:}

Rosihanari, 2017. Setting Gammu Untuk Aplikasi SMS Gateway, http:// blog.rosihanari.net/setting-gammu-untukaplikasi-sms-gateway, diakses 27 Juni 2017. Tyas, Brigida, 2017. SMS Gateway, http:// informatika.web.id/short-messageservice.htm\#more-1252, diakses 30 Juni 2017.

\section{(Footnotes)}

${ }^{1}$ Eddy Prahasta. Sistem Informasi Geografis : Konsepkonsep Dasar (Perspektif Geodesi \& Geomatika). (Bandung: Informatika, 2009), hal. 32

${ }^{2}$ Daniel Jacobson, Greg Brail \& Dan Woods. APIs: $A$ Strategy Guide. (USA:O'reilly, 2012), hal. 1

${ }^{3}$ https://developers.google.com/places/javascript/, diakses, 17 Juni 2017

${ }^{4}$ https://www.researchgate.net/figure/

221611936_fig1_Figure-1-Typical-handset-to-handsetnetwork-architecture-for-SMS, diakses 23 April 2017

${ }^{5} \mathrm{http}: / /$ blog.rosihanari.net/setting-gammu-untukaplikasi-sms-gateway, diakses 27 Juni 2017

${ }^{6}$ isi-ska.ac.id/pengumuman/2017/07/pengumuman-daftarpeserta-dan-jadwal-pembekalan-kkn-2017-isi-surakarta, diakses 7 Juli 2017

${ }^{7}$ http://tekno.liputan6.com/read/2325781/inilah-operatoryang-merajai-cakupan-jaringan-4g-di-indonesia, diakses 18 Juni 2017

${ }^{8} \mathrm{http} / / /$ laman.temanggungkab.go.id/info/detail/2/26/petaadministrasi.html, diakses 8 Juli 2017

${ }^{9}$ Sumber : hasil observasi lapangan : I Putu Suhada Agung, M.Eng. \& Sapto Hudoyo, S.Sn., M.A. 